\title{
TANIO, SKUTECZNIE, BEZPIECZNIE? NOWA ANALIZA INSTYTUCJONALNA I JEJ WIZJA INSTYTUCJI SPOŁECZNEJ
}

\begin{abstract}
Teoinstytucjonalizm, zwany także nową analizą instytucjonalną 1 (NAI), jest obecna w naukach społecznych i ekonomicznych od kilkudziesięciu lat perspektywą teoretyczną. Zapoczątkowany w latach 30. ubiegłego stulecia w Stanach Zjednoczonych doczekał się różnorodnych dróg kontynuacji. $\mathrm{Na}$ polskim gruncie jest jednak problematyką nową, nieczęsto jeszcze wykorzystywaną w praktyce badawczej i - mówiąc krótko - mało znaną ${ }^{1}$. Celem niniejszej pracy będzie przede wszystkim prezentacja podstawowych założeń nowej analizy instytucjonalnej - zwłaszcza tych, którymi zainteresowały się nauki społeczne. Podejmę również próbę oceny neoinstytucjonalizmu z socjologicznego punktu widzenia. Wnioski zawarte w tekście posłużą odpowiedzi na pytanie, w jakim stopniu NAI jest "nową jakością" w socjologicznych refleksjach nad instytucjami? Jaką wizję instytucji społecznej proponuje?

Wprowadzeniem w arkana nowej analizy instytucjonalnej moga być słowa wybitnego przedstawiciela nurtu, laureata nagrody Nobla w dziedzinie ekonomii (1993 r.) - Douglassa C. Northa: "Instytucje to stworzone przez człowieka ograniczenia, które strukturyzują interakcje

\footnotetext{
${ }^{1}$ Dowodem nowatorskiego charakteru neoinstytucjonalizmu na gruncie polskich nauk społecznych może być fakt nielicznych wciąż publikacji na ten temat. Jak dotąd w Polsce nie ukazała się np. fundamentalna dla nurtu praca Douglassa C. Northa Institutions, Institutional Change and Economic Performance, ogłoszona przez autora w $1990 \mathrm{r}$. Zob.: http:www.nobel.se/economics/laureates/1993/north-autobio.html. Większość polskich prac stanowią artykuły socjologów, przybliżających zasadnicze założenia analizy neoinstytucjonalnej.
} 
polityczne, ekonomiczne i społeczne. Składaja się na nie ograniczenia nieformalne (sankcje, tabu, zwyczaje, tradycje, nieformalne kodeksy zachowań) oraz reguły sformalizowane (konstytucje, prawo, prawa własności). W ciagu historii instytucje zostały wykreowane przez ludzi w celu stworzenia porządku oraz zredukowania niepewności w transakcjach"2. U podstaw tego interdyscyplinarnego nurtu, obecnego w socjologii (zwłaszcza socjologii prawa i organizacji), prawie, ekonomii, historii gospodarczej czy naukach politycznych, leży przekonanie, że o kształcie i jakości procesów społecznych zachodzących we współczesnym świecie decyduja przede wszystkim instytucje społeczne. Są one traktowane jako ważna zmienna, a nawet konstytutywna część zmian społecznych, ekonomicznych czy politycznych ${ }^{3}$. Jednostki, grupy czy organizacje, które znalazły się w sytuacji wyboru, będa w procesie podejmowania decyzji odwoływały się do instytucji - to one wskazuja bowiem gamę możliwości postępowania i formułują alternatywy. ${ }^{4}$.

Instytucje społeczne to $\mathrm{w}$ ujęciu przedstawicieli nurtu również swoiste gwaranty bezpieczeństwa podejmowanych przez ludzi działań. Jak pisze Ronald Coase, instytucje pomagają ludziom zmniejszać koszty transakcji społecznych i przyczyniają się do redukcji niepewności, jaką niosą za sobą owe transakcje. Dzięki scedowaniu odpowiedzialności na poziom instytucjonalny jednostki ponoszą mniejsze koszty transakcyjne niż gdyby zdecydowały się wejść w interakcję bez pomocy pośrednika ${ }^{5}$. Z powyższej, skrótowej charakterystyki wyłaniają się wizje instytucji społecznej jako bytu zapewniającego jednostce bezpieczeństwo, regularność i niski koszt interakcji, a także człowieka, jako działającego w imię zysku racjonalisty. Dążenie do maksymalizacji zysków jest jednak tylko jednym z motywów ludzkich zachowań - nie mniej ważny jest tu fakt przyswojenia sobie przez jednostkę składających się na ład instytucjonalny norm i wartości ${ }^{6}$.

Sporo miejsca w poświęconych neoinstytucjonalizmowi pracach polskich autorów zajmuja problemy definicyjne. Analiza instytucjonalna, choćby ze względu na swą wewnętrzną różnorodność, prezentuje co najmniej kilka definicji instytucji społecznej. Funkcjonujący w ramach nurtu politologowie definiując instytucję, kłada nacisk na procesy

\footnotetext{
${ }^{2}$ Cyt. za: G. Skapska, Neoinstytucjonaližm, w: Encyklopedia socjologii, t. 2, Oficyna Naukowa, Warszawa 1999, s. 324.

3 Tamże, s. 324-325.

4 Cyt. za: W. Pawlak, Instytucje $i$ zmiana instytucjonalna $w$ teorii D. Northa, "Studia Socjologiczne", 1993, nr 1, s. 68.

5 Tamże, s. 69-70.

${ }^{6}$ G. Skapska, Neoinstytucjonalizm, dz. cyt., s. 325.
} 
Tanio, skutecznie, bezpiecznie?... 153

decyzyjne zachodzące w jej ramach: kto podejmuje decyzje, jak odbywa się przepływ informacji? Ekonomiści z kolei postrzegaja instytucję jako "zwyczaje i reguły, które dostarczają jednostkom układu zachęcającego do działania i hamującego działania"7. Definicja Hardina mówi o instytucji jako o "adaptacyjnym rozwiązaniu problemu", polegającym na kalkulacji kosztów podejmowanych interakcji społecznych. Wymienione definicje łączy z pewnością kryjące się za nimi pytanie: jak dochodzi do zinstytucjonalizowanych, racjonalnych działań ludzkich? Jak pisze polski znawca problematyki NAI, socjolog Piotr Chmielewski, różnorodne definicje instytucji społecznej sprowadzić można do wspólnego mianownika, jakim jest teoria kapitału społecznego Jamesa Colemana. Według tej właśnie koncepcji w toku działania, wymiany informacji, rozwiązywania dylematów związanych z kosztami interakcji wytwarza się niezbędny jednostce do funkcjonowania w społeczeństwie kapitał zasoby materialne i symboliczne, które sprzyjają instytucjonalizacji życia zbiorowego". Warto jednak zatrzymać się dłużej nad pytaniem o to jak powstaja rozmaicie definiowane instytucje społeczne. Refleksja nad problemem wyłaniania się instytucji jest nie tylko ważna dla zrozumienia głównych założeń NAI. Będzie to również okazja do zaprezentowania teoretycznych korzeni neoinstytucjonalizmu.

Wojciech Pawlak i Grażyna Skapska w swych artykułach zaprezentowali stanowiska nurtu w kwestii powstawania instytucji społecznych. Ponieważ oba zestawienia oparte są na czytelnej dychotomii, łatwo dokonać ich analizy porównawczej. Koncepcje powstania instytucji nazwę za Skapską organiczną i konstruktywistyczna. Według pierwszej koncepcji, odwołującej się do myśli Davida Hume`a i idei "niewidzialnej ręki rynku" Adama Smitha, instytucje są efektem ewolucyjnego, wzajemnego przystosowywania się działających racjonalnie jednostek. Rezultatem egoistycznie umotywowanych zachowań ludzkich są właśnie instytucje społeczne, których zadaniem jest jedynie nakładanie na jednostki zaakceptowanych przez nie ograniczeń. Koncepcja konstruktywistyczna kładzie zaś nacisk na świadomy wybór $\mathrm{i}$ umowę społeczną jako fundamenty instytucji społecznych. Ponieważ jednostki podzielaja pewne cele i wartości, podobnym celom służą też instytucje, które będą stały na straży samorządności i swobód obywatelskich oraz pomagały w kalkulacji

7 P. Chmielewski, Nowa analiza instytucjonalna. Logika $i$ postawowe zasady. "Studia Socjologiczne", 1994, nr 3-4, s. 240.

${ }^{8}$ Zob.: W. Pawlak, Instytucje $i$ zmiana instytucjonalna..., dz. cyt., s. 67-68.

${ }^{9}$ P. Chmielewski, Nowa analiza instytucjonalna..., dz. cyt., s. 241-242. 
kosztów transakcyjnych. Jak zauważa Skapska, dwa odmienne stanowiska odpowiadaja dwóm głównym nurtom neoinstytucjonalizmu odpowiednio: utylitarystycznemu i kulturowo-politycznemu ${ }^{10}$.

Powyżej zasygnalizowane zostały dwa znaczące, choć nie jedyne źródła neoinstytucjonalizmu: liberalizm i utylitaryzm. Ważną inspiracją NAI były także teorie racjonalnego wyboru oraz amerykańska szkoła instytucjonalizmu ekonomicznego, której kontynuatorami określają się często neoinstytucjonaliści. Koncepcjom racjonalnego wyboru analiza instytucjonalna zawdzięcza przede wszystkim koncepcję człowieka jako racjonalnie działającej jednostki, dążącej do zmaksymalizowania zysków, jakie niosą zawiązywane przez niego interakcje społeczne oraz podejmowane decyzje $\mathrm{e}^{11}$. Z ową wizją jednostki wiąże się stanowisko indywidualizmu metodologicznego, opisującego świat społeczny przez pryzmat jednostki i jej działań. Konsekwencją przyjętej strategii metodologicznej jest definiowanie instytucji społecznej - jak już wspomniano wcześniej - jako zbioru reguł, ograniczającego jednostkowe działania ludzkie. Człowiek badany przez instytucjonalistów, zwłaszcza zorientowanych utylitarnie, to człowiek ograniczany rozwiązaniami instytucjonalnymi, zawsze mający na uwadze koszty interakcji, w jakie wchodzi.

Ekonomia instytucjonalna Thorsteina Veblena, autora m.in. głośnej Teorii klasy próżniaczej, wyposażyła neoinstytucjonalizm w dynamiczne spojrzenie na instytucję społeczną, którą autor uznawał za czynnik i wynik procesu adaptacji społecznej jednocześnie. Veblen traktował rynek jako twór podlegający procesom ewolucyjnej zmiany, inspirowanej przez przemiany instytucjonalne ${ }^{12}$. Ogromne znaczenie dla rozwoju NAI miały wreszcie, rozwijane $\mathrm{w}$ ramach teorii racjonalnego wyboru, teorie gier. Warto wspomnieć tu o koncepcji wspólnej puli zasobów (Common Pool Resources [CPR]) Elinor Ostrom. Badaczka przedstawiła w niej wieloosobowy wariant tzw. dylematu więźnia - znanego w socjologii schematu zachowań dwóch oskarżonych o przestępstwo, analizującego ich potencjalne korzyści i straty w sytuacjach, gdy zechcą współpracować przy zeznaniach bądź też zaczną denuncjować siebie nawzajem ${ }^{13}$. Ostrom posłużyła się m. in. przykładem rybaków, którzy poławiając ryby

10 W. Pawlak, Instytucje $i$ zmiana instytucjonalna..., dz. cyt., s. 66; G. Skapska, Neoinstytucjonalizm, dz. cyt.

11 Zob. np.: P. M. Blau, Wymiana nagród spotecznych, w: Wspótczesne teorie wymiany spotecznej. Zbiór tekstów, pod red.. M. Kempnego, J. Szmatki, PWN, Warszawa 1992, s. 230-243.

12 W. Pawlak, Instytucje i zmiana instytucjonalna..., dz. cyt., s. 69.

13 K. Olechnicki, P. Załęcki, Stownik socjologiczny, Wydawnictwo Graffiti BC, Toruń 1998, s. 49. 
na własny rachunek, bez jakiejkolwiek współpracy i ustalenia zasad, doprowadzaja do szybkiego wyeksploatowania zasobów akwenu. W sytuacji, gdy ludzie muszą wspólnie gospodarować niezbyt obfitymi zasobami, bardziej opłacalna jest kooperacja aniżeli agresywna, przynosząca jedynie doraźne korzyści postawa egoistyczna konkludowała autorka koncepcji $\mathrm{CPR}^{14}$. W tym ujęciu instytucje, czyli ustalane przez ludzi reguły wspólnego zarządzania zasobami, przywodza na myśl znaną, weberowską definicję władzy jako sztuki rozsądnego gospodarowania niedostatkiem.

Dokonując próby oceny nowej analizy instytucjonalnej chciałabym rozpocząć od kwestii, które socjologom niewątpliwie wydadzą się kontrowersyjne. Zarzutem, jaki postawić można koncepcji NAI, jest fakt, iż posługuje się ona "przeinstytucjonalizowaną" wizją świata społecznego. Każde zachowanie ludzkie, które cechuje się choćby minimalna dozą regularności, jest przez przedstawicieli nurtu określane mianem instytucji społecznej ${ }^{15}$. W analizach cytowanych autorów nieobecna jest bogata i różnorodna skądinąd typologia form organizacji życia społecznego, takich jak choćby zrzeszenia czy niesformalizowane grupy celowe. "Analiza instytucjonalna to $z$ jednej strony swoisty inwentarz problemów społecznych, a $z$ drugiej to analiza typów porządku społecznego pod kątem tworzonych przez nie ograniczeń i możliwości wyboru w życiu człowieka" - przekonuje Piotr Chmielewski1 ${ }^{16}$. Czy rzeczywiście? Zarówno niepisane reguly typu fair play, jak i wysoce zinstytucjonalizowany świat polityki reprezentanci NAI traktuja tak, jakby nie było między nimi żadnych różnic jakościowych; jak gdyby obie w takim samym stopniu wpływały na dokonywane przez ludzi wybory. Bardzo szerokie, specyficzne pojęcie instytucji społecznej nasuwa myśl, że oto bezużyteczne stają się wszelkie inne terminy, opisujące regularne, zorganizowane zachowania: norma, rytuał, grupa, zwyczaj, naśladownictwo itp. - wszystko jest wszakże instytucją.

14 Po raz pierwszy w Polsce koncepcję CPR omówił i przeanalizował Marek M. Kamiński w artykule Dylematy społeczne w ujęcin Elinor Ostrom, "Kultura i Społeczeństwo", 1992, nr 2, s. 137-140.

15 Należy zauważyć w tym miejscu, że socjologia, jak i inne nauki społeczne nie proponuje jednej, całościowej definicji instytucji społecznej. Szerokie spektrum owych definicji przedstawił Kazimierz Sowa w pracy pt. Wstęp do socjologicznej teorii żæzeszeńn. Autor wskazał jednakże na takie cechy instytucji społecznej, które różnia ją zasadniczo od innych form organizacji życia zbiorowego m.in. wysoki stopień formalizacji, przymusowość, wyodrębnienie klienteli i personelu instytucji. Zob. K. Z. Sowa, Wstęp do socjologicznej teorii zrzeszen, PWN, Warszawa 1988, s. 19-49.

16 P. Chmielewski, Nowa analiza instytucjonalna..., dz. cyt., s. 242. 
Kolejny zarzut wobec nowej analizy instytucjonalnej dotyczy zbyt optymistycznych założeń, na jakich się opiera. Po pierwsze - zadaniem instytucji społecznej w myśl NAI ma być redukcja niepewności, jaką niosa nowe interakcje oraz tworzenie nowych, efektywnych wzorców życia społecznego. Tymczasem, jak pokazuja np. prowadzone przez amerykańskich badaczy krytyczne analizy systemów biurokratycznych, na instytucjach nie zawsze można polegać - same generują bowiem chaos i niesterowność, którym miały zapobiegać ${ }^{17}$. Przewidywalność i regularność transakcji społecznych, jaką zapewniać ma instytucja jest niekiedy - paradoksalnie - nieefektywna i niepożądana. Zjawisko to George Ritzer nazwał nieracjonalna racjonalnościa. Jak dowodził w swojej pracy Makdonaldyzacja spokeczeństwa ujednolicona, ograniczona, skonstruowana na wzór barów fast-food strategia działania instytucji społecznych często budzi niezadowolenie petentów, gdyż nie uwzględnia różnorodności i indywidualnego charakteru ich potrzeb ${ }^{18}$. Po wtóre zaś pewne zastrzeżenia budzi czerpiąca $\mathrm{z}$ tradycji homo oeconomicus antropologia neoinstytucjonalizmu, zwłaszcza w jego ekonomicznoutylitarnej wersji. Warto $\mathrm{w}$ tym miejscu postawić pytanie: czy nowa analiza instytucjonalna $\mathrm{i}$ jej wizja jednostki pozostawiaja człowiekowi jakikolwiek margines działań nieracjonalnych? Jak wytłumaczyć zachowania ludzi, którzy wybierają kosztowniejsze, niepopularne społecznie i trudniejsze ścieżki interakcji? Z drugiej strony - czy „pójście na skróty": oszustwo, przestępstwo, społeczne pasożytnictwo to także droga do ustandaryzowanych, efektywnych wzorów życia zbiorowego?

Mimo powyższych minusów nie sposób odmówić teorii neoinstytucjonalnej kilku istotnych $\mathrm{z}$ naukowego punktu widzenia atutów. Za najważniejszy z nich uznałabym przedefiniowanie stosunków człowiek - instytucja. W klasycznych już we współczesnej humanistyce koncepcjach Michela Foucault, Michela Crozier czy Ervinga Goffmana na pierwszy plan wysuwa się problem uprzedmiotowienia jednostki przez instytucję, która ukazywana jest jako struktura wszechogarniająca, przymusowa, dyscyplinująca, zdehumanizowana. Przedstawiciele nowej analizy instytucjonalnej zaproponowali wizję alternatywną: instytucja wprawdzie kształtuje człowieka, ale i człowiek tworzy instytucje - jak

17 Zob np. M. Crozier, E. Friedberg, Cz̨łowiek i system. Ograniczenia działania zespotowego, PWE, Warszawa 1982, s. 121, 183-185; R. Hull, L. J. Peter, Zasada Petera. Dlaczego wszystko idzie na opak, Książka i Wiedza, Warszawa 1975.

18 G. Ritzer, Makedonaldyzacja społeczeństwa, Muza SA, Warszawa 1997. 
Tanio, skutecznie, bezpiecznie?... 157

ująby to Thorstein Veblen. ${ }^{19} \mathrm{~W}$ neoinstytucjonalnym ujęciu zacierają się różnice pomiędzy personelem a klientelą instytucji - nierzadko jednostka odgrywa obie role naraz. Instytucja jest tu raczej miejscem wyboru, samorządności, wspólnego poszukiwania efektywnych dróg życia społecznego, nie zaś przymusowego, narzuconego odgórnie wzoru działań.

Również w neoinstytucjonalnej koncepcji jednostki odnaleźć można interesujące z socjologicznego punktu widzenia elementy. Człowiek widziany oczyma instytucjonalistów nie jest istotą jednowymiarową. Dzięki prowadzonym w ramach omawianego nurtu badaniom socjologicznym i politologicznym doszło do zbliżenia dwóch wizji jednostki ludzkiej. Koncepcja "człowieka ekonomicznego" wzbogacona została o cechy homo politicus - człowieka-obywatela, skłonnego do kooperacji i renegocjowania zasad gier społecznych, zainteresowanego pielęgnowaniem więzi zbiorowych ${ }^{20}$. Jak pokazują zaprezentowane wcześniej warianty teorii gier społecznych Elinor Ostrom, współpraca jest nierzadko bardziej korzystna od forsowania indywidualnej, eksploatatorskiej strategii. Ekonomiczna kooperacja okazuje się swoista szkołą demokracji, gdyż w praktyczny, angażujący wszystkich zainteresowanych sposób uczy oddolnej budowy ładu społecznego. Samorządny i demokratyczny ustrój, zdaniem Ostrom, współczesne społeczeństwa zawdzięczają właśnie eksperymentom z różnymi formami współpracy międzyludzkiej. ${ }^{21} \mathrm{~W}$ swoich analizach kultur politycznych Gabriel Almond i Sidney Verba dowodzili, iz w podobny sposób - w drodze otwartego dyskursu i szukania "złotego środka" pomiędzy postawą zachowawczą a postępową - rodzi się obywatelska kultura polityczna, będąca jedną $z$ fundamentalnych instytucji (w szerokim tego słowa znaczeniu) demokratycznego społeczeństwa ${ }^{22}$.

Nowa analiza instytucjonalna wydaje się być interesująca propozycja teoretyczną $z$ uwagi na swą genezę i interdyscyplinarność. Pomimo dyskusyjnych, jak starałam się pokazać, kwestii definicyjnych wizja instytucji społecznej zaproponowana przez neoinstytucjonalistów jest wizją bardzo przydatną $i$ aktualną, nasuwającą myśl o jednej $z$ najważniejszych teorii organizacji życia społecznego $\mathrm{w}$ historii nauk społecznych. Mowa tu o koncepcji racjonalizacji Maxa Webera. W

19 Zob.: P. Chmielewski, Nowa analiza instytucjonalna..., dz. cyt., s. 219.

${ }^{20}$ G. Skąpska, Neoinstytucjonalizm, dz. cyt., s. 325-326.

${ }^{21}$ P. Chmielewski, Nowa analiza instytucjonalna..., dz. cyt., s. 243.

${ }^{22}$ G. Almond, S. Verba, Kultura polityczna, w: Wtadza i spoteczeństwo. Antologia tekstón z. zakeresu socjologii polityki, pod red. J. Szczupaczyńskiego, Wydawnictwo Naukowe Scholar, Warszawa 1995, s. 328-344. 
świetle NAI o instytucjonalnym charakterze danego faktu społecznego stanowi nie tyle struktura organizacyjna, urządzenia instytucjonalne, personel, aparat egzekucyjny czy zasada członkostwa - jak głoszą teorie socjologii organizacji. Każdy zorganizowany, ustrukturyzowany przejaw życia społecznego (jak choćby reguła językowa czy obyczaj) zyskuje miano instytucji - stając się tym samym regulatorem transakcji społecznej, pozwalajacym oszacować jej koszty i wybrać najlepszy wariant. W tychże drobnych elementach, którym reprezentanci NAI nadają status instytucji, można by dopatrywać się podobieństw do racjonalnych zasad, odgrywających według Maxa Webera kluczową rolę w regulowaniu życia publicznego: racjonalizacji, kalkulacji, posłuszeństwa, wydajności, a także towarzyszącemu im swoistego etosu $^{23}$.

Innym plusem teorii neoinstytucjonalnej, zwłaszcza w polskich realiach, może być jej użyteczność w badaniach nad instytucjami oraz przemianami ładu społecznego w okresie transformacji. Upadek monocentrycznego porządku i wyłanianie się nowych instytucji życia społecznego, takich jak wolny rynek, pluralistyczna scena polityczna czy sektor pozarządowy, mógłby być znakomitym sprawdzianem empirycznym dla teorii, na której w Polsce nie oparto jeszcze poważniejszych projektów badawczych. Nielicznymi wyjątkami sa tu analiza polskiej bankowości przeprowadzona przez Marka Zarzyckiego ${ }^{24}$ oraz praca Strategie i system, zrealizowana przez zespół socjologów z PAN pod kierunkiem Andrzeja Rycharda. Czerpiąc z teorii kapitału społecznego oraz neoinstytucjonalistycznych założeń badacze poszukuja w danych empirycznych odpowiedzi na pytanie o to, jak zaradni są w dobie przemian społecznych Polacy i na ile potrafią korzystać ze stwarzanych przez życie społeczne sposobności - od kontaktów międzyludzkich w najbliższym środowisku po możliwość oddania głosu w wyborach ${ }^{25}$. Zaproponowane przez badaczy dwa dychotomiczne porządki wewnątrz neoinstytucjonalizmu mogłyby być z kolei inspirujące nie tylko dla przedstawicieli nauk społecznych, ale także polityków, publicystów i wszystkich uczestników debat publicznych, poświęconych przemianom ustrojowym w Polsce. Doskonale odzwierciedlaja one obecne w życiu nowoczesnych społeczeństw dylematy, dotyczące

23 Z. Krasnodębski, Max Weber, Wiedza Powszechna, Warszawa 1999, s. 178-199.

${ }^{24}$ M. Zarzycki, Kształtowanie sie systemu bankowego - próba analizy instytucjonalnej, "Studia Socjologiczne", nr 1, s. 77-96.

25 A. Giza-Poleszczuk, M. Marody, A. Rychard, Strategie i system. Polacy w obliçu zmiany spotecznej, Wydawnictwo IFiS PAN, Warszawa 2000. 
Tanio, skutecznie, bezpiecznie?... 159

instytucjonalnej sfery życia zbiorowego. Ład spontaniczny czy konstruowany? Wolny rynek czy państwo opiekuńcze? Liberalizm czy egalitaryzm? Samorządność czy etatyzm? Regulacja prawna czy czekanie na samoistne przemiany w pożądanym kierunku? Podtrzymywanie więzi wspólnotowej czy wymiana dóbr?

Reasumując, stwierdzić można, że znaczenie, jakie ma dla współczesnych nauk społecznych neoinstytucjonalizm, przejawia się przede wszystkim w jego refleksjach nad tym, jak ogromne znaczenie mają ludzkie zachowania dla wyłaniania się ładu instytucjonalnego, który z kolei znacząco wpływa na życie jednostek i grup społecznych. Choć zaprezentowane w niniejszym tekście teorie nie przynosza jednoznacznej odpowiedzi na pytanie o to, czy instytucje społeczne rzeczywiście gwarantuja ludziom bezpieczeństwo i mniejsze koszty społecznych interakcji, z pewnościa trafnie opisuja proces kształtowania się sfery instytucji we współczesnych, dynamicznie rozwijających się społeczeństwach. 